Article

\title{
Soil Organic Carbon and Labile Carbon Pools Attributed by Tillage, Crop Residue and Crop Rotation Management in Sweet Sorghum Cropping System
}

\author{
Mashapa Elvis Malobane ${ }^{1,2, *(1)}$, Adornis Dakarai Nciizah ${ }^{1,2}$, Fhatuwani Nixwell Mudau $2,3(1)$ \\ and Isaiah Iguna Chabaari Wakindiki ${ }^{2,4}$ (D) \\ 1 Agricultural Research Council-Institute for Soil, Climate and Water, P. Bag X79, Pretoria 0083, South Africa; \\ NciizahA@arc.agric.za \\ 2 Department of Agriculture and Animal Health, University of South Africa, Private Bag X6, \\ Florida 1710, South Africa; MudauF@ukzn.ac.za (F.N.M.); iwakindiki@gmail.com (I.I.C.W.) \\ 3 School of Agricultural, Earth and Environmental Sciences, University of Kwazulu Natal, P. Bag X01, \\ Scottsville, Pietermaritzburg 3209, South Africa \\ 4 Jaramogi Oginga Odinga University of Science and Technology, P.O. Box, Bondo 210-40601, Kenya \\ * Correspondence: malobanem@arc.agric.za
}

Received: 23 October 2020; Accepted: 13 November 2020; Published: 23 November 2020

check for updates

\begin{abstract}
Labile organic carbon (LOC) fractions are considered as sensitive indicators of change in soil quality and can serve as proxies for soil organic carbon (SOC). Although the impact of tillage, crop rotation and crop residue management on soil quality is well known, less is known about LOC and SOC dynamics in the sweet sorghum production systems in South Africa. This short-term study tested two tillage levels: no-till and conventional-tillage, two crop rotations: sweet-sorghum/winter grazing vetch/sweet sorghum and sweet-sorghum/winter fallow/sweet sorghum rotations and three crop residue retention levels: $30 \%, 15 \%$ and $0 \%$. Tillage was the main factor to influence SOC and LOC fractions under the sweet sorghum cropping system in South Africa. NT increased SOC and all LOC fractions compared to CT, which concurs with previous findings. Cold water extractable organic carbon (CWEOC) and hot water extractable organic carbon (HWEOC) were found to be more sensitive to tillage and strongly positively correlated to SOC. An increase in residue retention led to an increase in microbial biomass carbon (MBC). This study concludes that CWEOC and HWEOC can serve as sensitive early indicators of change in soil quality and are an ideal proxy for SOC in the sweet-sorghum cropping system in South Africa.
\end{abstract}

Keywords: conservation agriculture; soil quality; no-till; land use

\section{Introduction}

The potential use of bioenergy sweet sorghum in South Africa, like in other countries, offers an opportunity for valuable use of marginal land and hence income to smallholder farmers at low agronomic inputs [1]. Biofuel feedstock production is generally done under intensive agronomic management [2], which has potential to reduce soil quality [3] and intensify soil erosion and its related consequences [4]. Thus, conserving and restoring soils in marginal lands is at the centre of sustainable production of bioenergy crops, and it will also serve as a poverty alleviation strategy [5]. According to Bonin and Lal [6], vegetation and management practices are the main factors influencing soil quality. However, to date, sustainable production systems for bioenergy sweet sorghum in South Africa are not available [7]. Conservation agriculture (CA) is currently promoted as a potential sustainable 
production for bioenergy sweet sorghum in South Africa [2]. However, research on the effect of CA on soil quality under the production of biofuel feedstock is required in South Africa [2]. Consequently, the potential benefits of CA under sweet-sorghum production systems for vital soil health indicators such as LOCs were not examined in depth.

Soil organic carbon (SOC) is one of the central carbon pools [8], regarded as the centre of soil quality and its functions and a leading indicator of soil health $[9,10]$. The depletion of SOC leads to poor soil aggregation and stability, loss in water holding capacity, fertility, enzymatic activities and soil biology [11]. Soil erosion and loss in soil productivity are among the visual consequences of SOC depletion [11,12]. Accelerated soil erosion increases carbon dioxide emission [13], which contributes to climate change [12]. Thus, maintaining and improvement of SOC are important for a sustainable production system and reduction in climate change [14,15].

Land use is the chief factor influencing SOC dynamics $[8,16,17]$. Continuous soil cultivation is known to increase the depletion of SOC by increasing SOC mineralization $[18,19]$. A less intensive agricultural system, no-till (NT), has been promoted as a system that enhances SOC and helps in climate change mitigation [19-21]. The extent and the rate of SOC increase when NT is adopted varies according to cropping system [20,22,23], soil type [24,25], climate [16,26,27] and other agronomic management practices [28-30]. Thus, SOC dynamics are both site and management specific when NT is adopted. In addition to NT, residue retention plays an important role in enhancing SOC [31-33]; however, residue retention effects may also be controlled by climate, soil type and other management aspects [34]. The change in SOC is also influenced by the crop(s) in rotation, in addition to the main crop [35,36]. Thus, more research on SOC as affected by tillage, crop residue management, crop rotation and nutrient management systems is still needed to advance our understanding of the SOC dynamics [15].

Soil organic carbon change is relatively slow; hence, total SOC only does not reflect sensitive changes in soil quality due to land use [11,37]. Labile organic carbon (LOC), a component of SOC, was found to be a good and sensitive early indicator of minor changes in soil after a change in land use $[11,37,38]$. LOC is the smallest part of SOC yet important in controlling nutrient availability to crops and microbes $[39,40]$. The change in LOC in given land use is controlled by site-specific conditions, vegetation, residue management and land-use intensity [41]. For that reason, inconsistency in the change in LOC resulting from land uses exists in literature [8]. Moreover, a lack of organic carbon, nitrogen, sulphur and other elements in the soil significantly influences sorghum and other cereal composition [1,42]. Thus, the aim of this study was to determine the effect of tillage, crop rotation and crop residue management on SOC and LOC pool dynamics in a sweet-sorghum production.

Although the goal in biofuel and food crops production is to maximize the harvested aboveground biomass, such management practices may have negative impacts on soil quality by decreasing SOC [43]. Therefore, it is important to determine the most suitable residue return levels that maintain or enhance SOC and its LOC pools.

\section{Materials and Methods}

\subsection{Site Description and Experimental Design}

The experiment was carried out at the University of Fort Hare experimental farm which is located at latitude $32^{\circ} 46^{\prime} \mathrm{S}$ and longitude $26^{\circ} 50^{\prime}$ E. Study site descriptions, treatments, experimental design and agronomic practices were as described by Malobane et al. [5]. Briefly, the experimental site climatic conditions are classified as semi-arid and it receives an annual mean rainfall of about $575 \mathrm{~mm}$ during the summer months. The dominant soil form at the experimental site is of alluvial origin, also known as Haplic Cambisol. The soil at the site has $60 \%$ sand, $18 \%$ silt, $22 \%$ clay, $\mathrm{pH}\left(\mathrm{H}_{2} \mathrm{O}\right) 6.98$ and SOC $11.5 \mathrm{~g} \mathrm{~kg}^{-1}$.

The experiment was conducted between October 2016 and March 2019. A randomised complete block designed with a $2 \times 2 \times 3$ split-split-plot arrangement, replicated three times, was used in this 
study. The main plot measured $12.8 \times 17 \mathrm{~m}$ and was assigned to tillage treatments (NT and CT). A sub-plot $(5.4 \times 17 \mathrm{~m})$ was assigned to crop rotations (S-V-S and S-F-S). Sub-sub-plots $(5.4 \times 5 \mathrm{~m})$ were assigned to crop residue management, $0 \%, 15 \%$ and $30 \%$ residue retentions of total fresh harvested biomass.

Sweet sorghum was planted in all the plots at 55,000 plants ha ${ }^{-1}$ in summer. An amount of $300 \mathrm{~kg} \mathrm{ha}^{-1}$ of 2:3:4(30) basal fertiliser was applied at sweet sorghum during sowing and $400 \mathrm{~kg} \mathrm{ha}^{-1}$ of limestone ammonium nitrate fertiliser as a top dressing at 6 weeks after sowing. Grazing vetch cover crop (Vicia dasycarpa cv. Max) was inoculated with Rhizobium leguminosarum biovar viciae and sown during winter in the allocated plots at recommended seed rates of $35 \mathrm{~kg} \mathrm{ha}^{-1}$. Glyphosate (N-(phosphono-methyl) glycine, $360 \mathrm{~g} \mathrm{~L}^{-1}$ ) was applied at $5 \mathrm{~L} \mathrm{ha}^{-1}$ to terminate the cover crop before seed development. Cylam 50EC (Lambda-cyhalothrin (pyrethroid), $50 \mathrm{~g} \mathrm{~L}^{-1}$ ) was used to control pests in the sweet sorghum crop. Weeds were controlled by hand hoeing in all plots whenever it was necessary.

\subsection{Sampling}

Soil samples for SOC and LOC were collected at the end of March 2019, after harvesting sweet-sorghum. The experimental treatments were carried out for a duration of 3 years before samples were collected. A composite sample made up of three random samples taken at $0.1 \mathrm{~m}$ depth in each plot was used for analysis. Noticeable crop residues were removed from the composite sample before analysis. The composite sample was divided into two portions: one for microbial mass carbon (MBC) and the other portion for SOC and LOC fractions. The determination of MBC was carried out on the same day the soils were collected. Composite samples for SOC and LOC analysis were air-dried and passed through a $2 \mathrm{~mm}$ sieve before analysis.

\subsection{Analysis}

Soil organic carbon (SOC) was determined using the Walkley black method. Particulate organic matter (POM) was determined using a method by Camberdella et al. [44]. Briefly, $10 \mathrm{~g}$ of air-dried soil was extracted with $30 \mathrm{~mL}$ Sodium hexametaphosphate solution $\left(5 \mathrm{~g} \mathrm{~L}^{-1}\right)$ in $100 \mathrm{~mL}$ sampling bottles and shaken horizontally for $18 \mathrm{~h}$. After $18 \mathrm{~h}$, the sample was then passed through a $0.053 \mathrm{~mm}$ sieve, and material remaining on the $0.053 \mathrm{~mm}$ sieve was then dried at $55^{\circ} \mathrm{C}$. The soil sample dried at $55{ }^{\circ} \mathrm{C}$ was then placed in a crucible and heated at $450^{\circ} \mathrm{C}$ for $4 \mathrm{~h}$ using a muffle furnace. POM was calculated using the formula below

$$
\mathrm{POM} \mathrm{mg} \mathrm{g}^{-1}=\left(\frac{\text { Weight at } 55^{\circ} \mathrm{C}-\text { Weight at } 450^{\circ} \mathrm{C}}{\text { Weight at } 55^{\circ} \mathrm{C}}\right) \times 1000
$$

Water extractable organic carbon was separated into two fractions, namely CWEOC and HWEOC [11]. The soil sample of $3 \mathrm{~g}$ air-dried sample was weighted in $30 \mathrm{~mL}$ polypropylene centrifuge tubes and extracted with $30 \mathrm{~mL}$ of distilled water at $30 \mathrm{rpm}$ for $30 \mathrm{~min}$. After extraction, the suspension was centrifuged at $3500 \mathrm{rpm}$ for $30 \mathrm{~min}$. To extract HWEC, $30 \mathrm{~mL}$ of distilled water was added into the sediments from CWEC extraction and vigorously shaken for $10 \mathrm{~s}$, capped and placed in a water bath at $80{ }^{\circ} \mathrm{C}$ for $16 \mathrm{~h}$. At the end of extraction, the tubes were vigorously shaken for $10 \mathrm{~s}$ and then centrifuged at $3500 \mathrm{rpm}$ for $30 \mathrm{~min}$. The organic $\mathrm{C}$ in the supernatant was determined using the Walkley Black method [35].

The chloroform fumigation-extraction procedure was used for the determination of $\mathrm{MBC}$ following the methods of Anderson and Ingram [45]. $K_{c}$ of 0.38 was used in the experimental trials [46].

\section{Statistical Analysis}

The JMP 14 was used to perform three-way analysis of variance (ANOVA). The least significant difference method at $p \leq 0.05$ was used for mean separations. 


\section{Results}

In this short-term study, SOC and LOC-i.e., MBC, CWEOC, HWEOC and POM-were mainly influenced by tillage (Table 1$)$. SOC and HWEOC were highly significantly $(p<0.01)$ influenced by tillage, while MBC, CWEOC and POM were only significantly $(p<0.05)$ influenced by tillage (Table 1$)$. No significant interaction among the three factors was found on SOC, CWEOC, HWEOC and POM, while MBC was influenced $(p<0.05)$ by tillage $\times$ rotation $\times$ residue management interaction (Table 1 ). In addition, MBC was strongly influenced $(p<0.001)$ by crop residue management (Table 1$)$.

Table 1. Analysis of variance (ANOVA) results of soil organic carbon (SOC), microbial biomass carbon (MBC), cold water extractable organic carbon (CWEOC), hot water extractable organic carbon (HWEOC) and particulate organic matter (POM) as influenced by tillage, crop rotation, crop residue management and their interaction.

\begin{tabular}{cccccc}
\hline & SOC & MBC & CWEOC & HWEOC & POM \\
\hline Till. & $0.0012^{* *}$ & $0.0367^{*}$ & $0.0143^{*}$ & $0.0050^{* *}$ & $0.0371^{*}$ \\
Rot. & 0.8407 & 0.1454 & 0.5942 & 0.1108 & 0.1166 \\
Res. man. & 0.9285 & $<0.0001^{* * *}$ & 0.2311 & 0.3485 & 0.3979 \\
Till. $\times$ Rot. & 0.7428 & 0.8268 & 0.2198 & 0.2349 & 0.2966 \\
Till. $\times$ Res. man. & 0.9380 & 0.9700 & 0.6570 & 0.4578 & 0.6612 \\
Rot. $\times$ Res. man. & 0.8506 & 0.4363 & 0.1894 & 0.4832 & 0.9620 \\
Till. $\times$ Rot. $\times$ Res. Man & 0.1528 & 0.0497 & 0.8582 & 0.7748 & 0.6014 \\
\hline
\end{tabular}

Till: tillage, Rot.: Rotation, Res. man: Residue management, ${ }^{*}, * *, * * *$ significant difference at $0.05,0.01$ and 0.001 , probability level, respectively.

The application of NT resulted in significantly higher SOC, MBC, CWEOC, HWEOC and POM compared to CT treatment (Table 2). SOC was $15.83 \%$ higher under NT compared to CT treatment (Table 2). MBC, CWEOC, HWEOC and POM, which form part of LOC, were $9.58 \%, 70.89 \%, 35.42 \%$ and $18.30 \%$ higher in NT compared to CT treatment, respectively. The measured LOC fractions constituted less than $35 \%$ of the total SOC.

Table 2. Effects of tillage on soil organic carbon (SOC), microbial biomass carbon (MBC), cold water extractable organic carbon (CWEOC), hot water extractable organic carbon (HWEOC) and particulate organic matter (POM).

\begin{tabular}{ccc}
\hline Measured Variables & \multicolumn{2}{c}{ Tillage Treatments } \\
\hline & NT & CT \\
\hline SOC $\left(\mathrm{mg} \mathrm{kg}^{-1}\right)$ & $10868.78 \mathrm{a}$ & $9382.72 \mathrm{~b}$ \\
MBC $\left(\mathrm{mg} \mathrm{kg}^{-1}\right)$ & $83.83 \mathrm{a}$ & $76.50 \mathrm{~b}$ \\
CWEOC $\left(\mathrm{mg} \mathrm{kg}^{-1}\right)$ & $38.28 \mathrm{a}$ & $22.40 \mathrm{~b}$ \\
HWEOC $\left(\mathrm{mg} \mathrm{kg}^{-1}\right)$ & $88.47 \mathrm{a}$ & $65.33 \mathrm{~b}$ \\
POM $\left(\mathrm{mg} \mathrm{kg}^{-1}\right)$ & $3492.93 \mathrm{a}$ & $2952.57 \mathrm{~b}$ \\
\hline
\end{tabular}

NB: NT: no-till, CT: conventional tillage, numbers followed by different letters within the same row show difference among the tillage systems.

Implementation of 30\% residue retention treatment favoured $\mathrm{MBC}$ regardless of tillage or crop rotation (Figure 1). NT + S-V-S + 30\% had 83.91\% higher MBC compared to CT + S-F-S + 0\% treatment combination, which is considered as common practice among smallholder farmers.

Residue retention of 30\% had significantly higher MBC compared to both $15 \%$ and $0 \%$ residue retention (Table 3). The 30\% residue retention had $35.85 \%$ and $51.50 \%$ higher MBC compared to $15 \%$ and $0 \%$ residue retentions, respectively. 


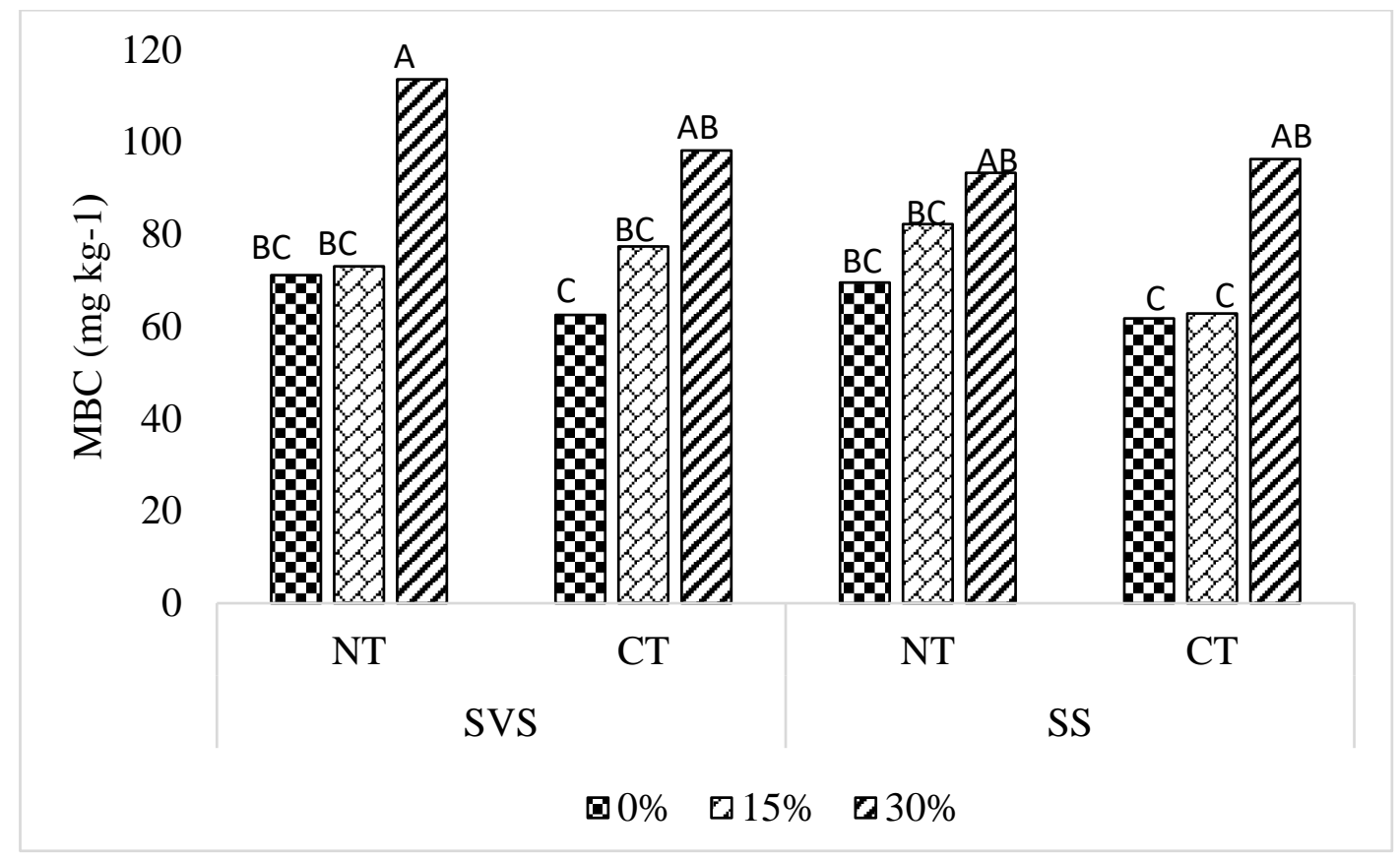

Figure 1. Tillage $\times$ rotation $\times$ residue management interaction effects on $\mathrm{MBC}\left(\mathrm{mg} \mathrm{kg}^{-1}\right)$. NT: no-till, CT: conventional tillage, SVS: sweet-sorghum/winter grazing vetch/sweet sorghum, SS: sweet sorghum/winter fallow/sweet sorghum. Different letter on the bars indicate differences among the treatment combinations.

Table 3. $\mathrm{MBC}\left(\mathrm{mg} \mathrm{kg}^{-1}\right)$ as influenced by crop residue management.

\begin{tabular}{cc}
\hline Residue Management & MBC $\left(\mathbf{m g ~ k g} \mathbf{~ g}^{-\mathbf{1}}\right)$ \\
\hline $0 \%$ & $66.25 \mathrm{~b}$ \\
$15 \%$ & $73.88 \mathrm{~b}$ \\
$30 \%$ & $100.37 \mathrm{a}$ \\
$p$ value $<0.001$ &
\end{tabular}

Numbers followed by different letters within the same row indicate differences among the treatments.

Soil organic carbon was positively correlated to all the selected LOC fractions: MBC, CWEOC, HWEOC and POM (Table 4). SOC was strongly correlated to HWEOC, and the lowest correlation was with MBC (Table 4). Selected LOC fractions were also positively correlated to each other (Table 4).

Table 4. Correlations between soil organic carbon (SOC), microbial biomass carbon (MBC), cold water extractable organic carbon (CWEOC), hot water extractable organic carbon (HWEOC) and particulate organic matter (POM).

\begin{tabular}{cccccc}
\hline & SOC & MBC & HWEOC & CWEOC & POM \\
\hline SOC & 1 & & & & \\
MBC & 0.17 & 1 & & & \\
HWEOC & 0.72 & 0.52 & 1 & & \\
CWEOC & 0.53 & 0.61 & 0.19 & 1 & \\
POM & 0.49 & 0.62 & 0.72 & 0.26 & 1 \\
\hline
\end{tabular}

\section{Discussion}

After 3 years of the sweet-sorghum production system in Eastern Cape, South Africa, SOC and selected LOC fractions significantly responded mainly to tillage. Tillage seems to able to alter the soil environment for microorganisms and SOC by increasing exposure of physically protected soil organic 
matter to microbial decomposition leading to a decline in SOC and biological activities $[18,19,47]$. Previous studies have demonstrated that some LOC fractions respond to changes in management faster and to a greater extent than SOC $[38,48]$. In this study, differences in LOC fractions between the tillage practices ranging between $9.58 \%$ and $70.89 \%$, while SOC was at $15.83 \%$, demonstrating that LOC fractions respond more to tillage than SOC.

The application of NT resulted in higher SOC and LOC fractions compared to CT treatment (Table 2). This is similar to previous findings [49-51]. Soil cultivation increases the influence of freezing-thawing and drying-rewetting cycles on soil properties, which increases aggregate disruption and accelerates the LOC mineralization and decline in SOC $[18,47,52]$. Our findings are in contrast with Zhao et al., who did not find a significant difference in SOC under NT and CT. The authors argued that their findings might mainly be due to environmental conditions on their site.

This study generally concurs with previous studies that reported LOC fractions to be sensitive to tillage $[51,53,54]$ apart from MBC for which percentage differences between NT and CT were less than that of SOC. Alvarez and Alvarez [55] also found that NT and CT had no influence on MBC. In this study, CWEOC was more sensitive to tillage than other LOC fractions. HWEOC was found to be higher than CWEOC, supporting previous studies $[48,56]$. The increase in LOC under NT is mainly due to the re-aggregation which protects the newly added carbon from residues [57]. Under the NT environment, biological activities are favoured, enhancing enzymes production which enhances LOC fractions $[58,59]$. The increase in LOC with NT application suggests that NT contributes to the improvement of soil functions as LOC is a vital energy source for soil micro-organisms which stimulate nutrient cycling, conserving soil quality and productivity [39].

The increase in MBC with residue retention (Table 3) is mainly due to residues offering nutrients for microbial growth and activity [60]. This supports previous studies that found an increase in MBC after residue retention management [61,62]. The increase in MBC is an indication of enhancement in soil health and gives an insight into the living SOC fraction [63]. In addition, the increase in MBC is a good indicator of overall biological activity which is crucial for nutrient cycling and availability [62]. The application of NT $+\mathrm{S}-\mathrm{V}-\mathrm{S}+30 \%$ which covers all the main principles of CA increased MBC more than the other treatment combinations, proving to be a potential management practice to exploit the benefits of CA in the sweet-sorghum production system in South Africa. The increase in MBC after implementation of NT, rotation and residue retention was previously reported [64]. Crop in rotation offers extra substrate for microbial growth and activity, which leads to an increase in MBC $[65,66]$.

The LOC fractions were positively correlated to SOC. This is in line with previous findings $[48,51,52,67]$. This suggests that the dynamics of LOC fractions can serve as an alternative to SOC changes in soils under agricultural and SOC is their major determinant in soil [51,52]. LOC is regarded as an important starting point for the establishment of stable SOC [68]. In this study, SOC was strongly correlated to HWEOC than other LOC fractions (Table 4), suggesting that HWEOC is a better proxy for SOC in the sweet-sorghum production system in South Africa and its monitoring will be crucial during restoration of marginal lands. Positive correlations among LOC fractions were also previously reported $[48,51,52,67]$. This is because LOC fractions are closely associated with each other [67].

\section{Conclusions}

Results from this study show that, in the short-term, SOC and LOC fractions studied under the sweet-sorghum production system in South Africa are more sensitive to tillage than to both residue retention and rotation management. The application of NT increased both SOC and all LOC fractions. The results also suggest that the various LOC fractions represent different SOC pools, with CWEOC and HWEOC representing pools that seem to be more sensitive to tillage. This makes them more suitable early indicators of soil quality than MBC, POM and SOC under a sweet-sorghum production system in South Africa. The fact that measured LOCs and SOC were not influenced by crop rotation and the interaction between tillage, crop rotation and residue retention warrants further studies. Therefore, 
studies evaluating treatments for a medium- to long-term period are recommended. In addition, inclusion of summer crop diversity/intercropping/crop rotation treatments is recommended for future studies in order to maximise biomass yield during the rainy season.

Author Contributions: Conceptualization, M.E.M. and A.D.N.; methodology, M.E.M. and A.D.N.; software, M.E.M.; validation, A.D.N., F.N.M. and I.I.C.W.; formal analysis, M.E.M. and A.D.N.; investigation, M.E.M. and A.D.N., F.N.M. and I.I.C.W.; data curation, M.E.M.; writing-original draft preparation, M.E.M.; writing-review and editing, A.D.N., F.N.M. and I.I.C.W.; supervision, A.D.N., F.N.M. and I.I.C.W.; project administration, A.D.N.; funding acquisition, A.D.N. All authors have read and agreed to the published version of the manuscript.

Funding: This work was supported by the National Research Foundation (grant number 98690).

Conflicts of Interest: The authors declare no conflict of interest.

\section{References}

1. Guerrini, L.; Napoli, M.; Mancini, M.; Masella, P.; Cappelli, A.; Parenti, A.; Orlandini, S. Wheat grain composition, dough rheology and bread quality as affected by nitrogen and sulfur fertilization and seeding density. Agronomy 2020, 10, 233. [CrossRef]

2. Malobane, M.E.; Nciizah, A.D.; Wakindiki, I.I.; Mudau, F.N. Sustainable production of sweet sorghum for biofuel production through conservation agriculture in South Africa. Food Energy Secur. 2018, 7, e00129. [CrossRef]

3. Dou, F.; Wight, J.P.; Wilson, L.T.; Storlien, J.O.; Hons, F.M. Simulation of biomass yield and soil organic carbon under bioenergy sorghum production. PLoS ONE 2014, 9, e115598. [CrossRef] [PubMed]

4. Lal, R. Crop residues as soil amendments and feedstock for bioethanol production. Waste Manag. 2008, 28,747-758. [CrossRef] [PubMed]

5. Malobane, M.E.; Nciizah, A.D.; Mudau, F.N.; Wakindiki, I.I. Tillage, Crop Rotation and Crop Residue Management Effects on Nutrient Availability in a Sweet Sorghum-Based Cropping System in Marginal Soils of South Africa. Agronomy 2020, 10, 776. [CrossRef]

6. Bonin, C.; Lal, R. Physical properties of an Alfisol under biofuel crops in Ohio. J. Technol. Innov. Renew. Energy 2012, 1, 1-13. [CrossRef]

7. Mengistu, M.; Steyn, J.M.; Kunz, R.; Doidge, I.; Hlophe, H.; Everson, C.S.; Jewitt, G.; Clulow, A. A preliminary investigation of the water use efficiency of sweet sorghum for biofuel in South Africa. Water SA 2016, 42, 152-160. [CrossRef]

8. Yu, P.; Han, K.; Li, Q.; Zhou, D. Soil organic carbon fractions are affected by different land uses in an agro-pastoral transitional zone in Northeastern China. Ecol. Indic. 2017, 73, 331-337. [CrossRef]

9. Lal, R.; Follett, R.F.; Stewart, B.A.; Kimble, J.M. Soil carbon sequestration to mitigate climate change and advance food security. Soil Sci. 2007, 172, 943-956. [CrossRef]

10. Zhao, S.; Li, K.; Zhou, W.; Qiu, S.; Huang, S.; He, P. Changes in soil microbial community, enzyme activities and organic matter fractions under long-term straw return in north-central China. Agric. Ecosyst. Environ. 2016, 216, 82-88. [CrossRef]

11. Ghani, A.; Dexter, M.; Perrott, K. Hot-water extractable carbon in soils: A sensitive measurement for determining impacts of fertilisation, grazing and cultivation. Soil Biol. Biochem. 2003, 35, 1231-1243. [CrossRef]

12. Lal, R. Climate change and soil degradation mitigation by sustainable management of soils and other natural resources. Agric. Res. 2012, 1, 199-212. [CrossRef]

13. Bhattacharya, S.S.; Kim, K.-H.; Das, S.; Uchimiya, M.; Jeon, B.H.; Kwon, E.; Szulejko, J.E. A review on the role of organic inputs in maintaining the soil carbon pool of the terrestrial ecosystem. J. Environ. Manag. 2016, 167, 214-227. [CrossRef] [PubMed]

14. Lal, R. Soil carbon sequestration to mitigate climate change. Geoderma 2004, 123, 1-22. [CrossRef]

15. Ghimire, R.; Lamichhane, S.; Acharya, B.S.; Bista, P.; Sainju, U.M. Tillage, crop residue, and nutrient management effects on soil organic carbon in rice-based cropping systems: A review. J. Integr. Agric. 2017, 16, 1-15. [CrossRef]

16. Willaarts, B.A.; Oyonarte, C.; Muñoz-Rojas, M.; Ibáñez, J.J.; Aguilera, P.A. Environmental factors controlling soil organic carbon stocks in two contrasting Mediterranean climatic areas of southern Spain. Land Degrad. Dev. 2016, 27, 603-611. [CrossRef] 
17. Lozano-García, B.; Muñoz-Rojas, M.; Parras-Alcántara, L. Climate and land use changes effects on soil organic carbon stocks in a Mediterranean semi-natural area. Sci. Total Environ. 2017, 579, 1249-1259. [CrossRef]

18. Lal, R. Sequestering carbon and increasing productivity by conservation agriculture. J. Soil Water Conserv. 2015, 70, 55A-62A. [CrossRef]

19. Lu, X.; Liao, Y. Effect of tillage practices on net carbon flux and economic parameters from farmland on the Loess Plateau in China. J. Clean. Prod. 2017, 162, 1617-1624. [CrossRef]

20. Shrestha, B.; Singh, B.; Forte, C.; Certini, G. Long-term effects of tillage, nutrient application and crop rotation on soil organic matter quality assessed by NMR spectroscopy. Soil Use Manag. 2015, 31, 358-366. [CrossRef]

21. Kibet, L.C.; Blanco-Canqui, H.; Jasa, P. Long-term tillage impacts on soil organic matter components and related properties on a Typic Argiudoll. Soil Tillage Res. 2016, 155, 78-84. [CrossRef]

22. de Oliveira Ferreira, A.; Amado, T.; Rice, C.W.; Diaz, D.A.R.; Keller, C.; Inagaki, T.M. Can no-till grain production restore soil organic carbon to levels natural grass in a subtropical Oxisol? Agric. Ecosyst. Environ. 2016, 229, 13-20. [CrossRef]

23. Mitchell, J.P.; Shrestha, A.; Mathesius, K.; Scow, K.M.; Southard, R.J.; Haney, R.L.; Schmidt, R.; Munk, D.S.; Horwath, W.R. Cover cropping and no-tillage improve soil health in an arid irrigated cropping system in California's San Joaquin Valley, USA. Soil Tillage Res. 2017, 165, 325-335. [CrossRef]

24. Chatterjee, A.; Lal, R. On farm assessment of tillage impact on soil carbon and associated soil quality parameters. Soil Tillage Res. 2009, 104, 270-277. [CrossRef]

25. Gonçalves, D.R.P.; de Moraes Sá, J.C.; Mishra, U.; Cerri, C.E.P.; Ferreira, L.A.; Furlan, F.J.F. Soil type and texture impacts on soil organic carbon storage in a sub-tropical agro-ecosystem. Geoderma 2017, 286, 88-97. [CrossRef]

26. Jobbágy, E.G.; Jackson, R.B. The vertical distribution of soil organic carbon and its relation to climate and vegetation. Ecol. Appl. 2000, 10, 423-436. [CrossRef]

27. Cai, A.; Feng, W.; Zhang, W.; Xu, M. Climate, soil texture, and soil types affect the contributions of fine-fraction-stabilized carbon to total soil organic carbon in different land uses across China. J. Environ. Manag. 2016, 172, 2-9. [CrossRef]

28. Díaz-Zorita, M.; Duarte, G.A.; Grove, J.H. A review of no-till systems and soil management for sustainable crop production in the subhumid and semiarid Pampas of Argentina. Soil Tillage Res. 2002, 65, 1-18. [CrossRef]

29. Suddick, E.C.; Scow, K.M.; Horwath, W.R.; Jackson, L.E.; Smart, D.R.; Mitchell, J.; Six, J. The potential for California agricultural crop soils to reduce greenhouse gas emissions: A holistic evaluation. In Advances in Agronomy; Elsevier: Amsterdam, The Netherlands, 2010; Volume 107, pp. 123-162.

30. Mazzoncini, M.; Sapkota, T.B.; Barberi, P.; Antichi, D.; Risaliti, R. Long-term effect of tillage, nitrogen fertilization and cover crops on soil organic carbon and total nitrogen content. Soil Tillage Res. 2011, 114, 165-174. [CrossRef]

31. Turmel, M.-S.; Speratti, A.; Baudron, F.; Verhulst, N.; Govaerts, B. Crop residue management and soil health: A systems analysis. Agric. Syst. 2015, 134, 6-16. [CrossRef]

32. Chen, H.; Liang, Q.; Gong, Y.; Kuzyakov, Y.; Fan, M.; Plante, A.F. Reduced tillage and increased residue retention increase enzyme activity and carbon and nitrogen concentrations in soil particle size fractions in a long-term field experiment on Loess Plateau in China. Soil Tillage Res. 2019, 194, 104296. [CrossRef]

33. Li, Y.; Li, Z.; Chang, S.X.; Cui, S.; Jagadamma, S.; Zhang, Q.; Cai, Y. Residue retention promotes soil carbon accumulation in minimum tillage systems: Implications for conservation agriculture. Sci. Total Environ. 2020, 140147. [CrossRef] [PubMed]

34. Govaerts, B.; Verhulst, N.; Castellanos-Navarrete, A.; Sayre, K.D.; Dixon, J.; Dendooven, L. Conservation agriculture and soil carbon sequestration: Between myth and farmer reality. Crit. Rev. Plant Sci. 2009, 28, 97-122. [CrossRef]

35. Dube, E.; Chiduza, C.; Muchaonyerwa, P. Conservation agriculture effects on soil organic matter on a Haplic Cambisol after four years of maize-oat and maize-grazing vetch rotations in South Africa. Soil Tillage Res. 2012, 123, 21-28. [CrossRef]

36. Shrestha, B.; McConkey, B.; Smith, W.; Desjardins, R.; Campbell, C.; Grant, B.; Miller, P. Effects of crop rotation, crop type and tillage on soil organic carbon in a semiarid climate. Can. J. Soil Sci. 2013, 93, 137-146. [CrossRef]

37. Benbi, D.K.; Brar, K.; Toor, A.S.; Singh, P. Total and labile pools of soil organic carbon in cultivated and undisturbed soils in northern India. Geoderma 2015, 237, 149-158. [CrossRef]

38. Geraei, D.S.; Hojati, S.; Landi, A.; Cano, A.F. Total and labile forms of soil organic carbon as affected by land use change in southwestern Iran. Geoderma Reg. 2016, 7, 29-37. [CrossRef] 
39. Chan, K.; Bowman, A.; Oates, A. Oxidizible organic carbon fractions and soil quality changes in an oxic paleustalf under different pasture leys. Soil Sci. 2001, 166, 61-67. [CrossRef]

40. Haubensak, K.A.; Hart, S.C.; Stark, J.M. Influences of chloroform exposure time and soil water content on C and $\mathrm{N}$ release in forest soils. Soil Biol. Biochem. 2002, 34, 1549-1562. [CrossRef]

41. Blanco-Moure, N.; Gracia, R.; Bielsa, A.C.; López, M.V. Soil organic matter fractions as affected by tillage and soil texture under semiarid Mediterranean conditions. Soil Tillage Res. 2016, 155, 381-389. [CrossRef]

42. Cappelli, A.; Oliva, N.; Cini, E. A Systematic Review of Gluten-Free Dough and Bread: Dough Rheology, Bread Characteristics, and Improvement Strategies. Appl. Sci. 2020, 10, 6559. [CrossRef]

43. Lal, R. Challenges and opportunities in soil organic matter research. Eur. J. Soil Sci. 2009, 60, 158-169. [CrossRef]

44. Cambardella, C.; Gajda, A.; Doran, J.; Wienhold, B.; Kettler, T.; Lal, R. Estimation of particulate and total organic matter by weight loss-on-ignition. In Assessment Methods for Soil Carbon; Lewis Publishers/CRC Press: Boca Raton, FL, USA, 2001; pp. 349-359.

45. Anderson, J.M.; Ingram, J.S.I. Tropical Soil Biology and Fertility: A Handbook of Methods; CABI: Wallingford, UK, 1994; Volume 4, p. 265.

46. Vance, E.D.; Brookes, P.C.; Jenkinson, D.S. An extraction method for measuring soil microbial biomass C. Soil Biol. Biochem. 1987, 19, 703-707. [CrossRef]

47. Six, J.; Elliott, E.; Paustian, K. Soil macroaggregate turnover and microaggregate formation: A mechanism for C sequestration under no-tillage agriculture. Soil Biol. Biochem. 2000, 32, 2099-2103. [CrossRef]

48. Benbi, D.K.; Kiranvir, B.; SHARMA, S. Sensitivity of labile soil organic carbon pools to long-term fertilizer, straw and manure management in rice-wheat system. Pedosphere 2015, 25, 534-545. [CrossRef]

49. Muñoz-Romero, V.; Lopez-Bellido, R.J.; Fernandez-Garcia, P.; Redondo, R.; Murillo, S.; Lopez-Bellido, L. Effects of tillage, crop rotation and $\mathrm{N}$ application rate on labile and recalcitrant soil carbon in a Mediterranean Vertisol. Soil Tillage Res. 2017, 169, 118-123. [CrossRef]

50. Naresh, R.; Purushottam, S.K.; Malik, M.; Kumar, S.; Choudhary, U. Effects of Tillage; Residue and nutrient management on top soil carbon stocks and soil labile organic carbon fractions in the Indo-gangetic plains of north west India: A review. J. Pharmacogn. Phytochem. 2018, 7, 1818-1842.

51. Bongiorno, G.; Bünemann, E.K.; Oguejiofor, C.U.; Meier, J.; Gort, G.; Comans, R.; Mäder, P.; Brussaard, L.; de Goede, R. Sensitivity of labile carbon fractions to tillage and organic matter management and their potential as comprehensive soil quality indicators across pedoclimatic conditions in Europe. Ecol. Indic. 2019, 99, 38-50. [CrossRef]

52. Chen, H.; Hou, R.; Gong, Y.; Li, H.; Fan, M.; Kuzyakov, Y. Effects of 11 years of conservation tillage on soil organic matter fractions in wheat monoculture in Loess Plateau of China. Soil Tillage Res. 2009, 106, 85-94. [CrossRef]

53. Ćirić, V.; Belić, M.; Nešić, L.; Šeremešić, S.; Pejić, B.; Bezdan, A.; Manojlović, M. The sensitivity of water extractable soil organic carbon fractions to land use in three soil types. Arch. Agron. Soil Sci. 2016, 62, 1654-1664. [CrossRef]

54. Prasad, J.; Rao, C.S.; Srinivas, K.; Jyothi, C.N.; Venkateswarlu, B.; Ramachandrappa, B.; Dhanapal, G.; Ravichandra, K.; Mishra, P. Effect of ten years of reduced tillage and recycling of organic matter on crop yields, soil organic carbon and its fractions in Alfisols of semi arid tropics of southern India. Soil Tillage Res. 2016, 156, 131-139. [CrossRef]

55. Alvarez, C.R.; Alvarez, R. Short-term effects of tillage systems on active soil microbial biomass. Biol. Fertil. Soils 2000, 31, 157-161. [CrossRef]

56. Soon, Y.; Arshad, M.; Haq, A.; Lupwayi, N. The influence of 12 years of tillage and crop rotation on total and labile organic carbon in a sandy loam soil. Soil Tillage Res. 2007, 95, 38-46. [CrossRef]

57. Jastrow, J.D.; Amonette, J.E.; Bailey, V.L. Mechanisms controlling soil carbon turnover and their potential application for enhancing carbon sequestration. Clim. Chang. 2007, 80, 5-23. [CrossRef]

58. Melero, S.; Panettieri, M.; Madejón, E.; Macpherson, H.G.; Moreno, F.; Murillo, J. Implementation of chiselling and mouldboard ploughing in soil after 8 years of no-till management in SW, Spain: Effect on soil quality. Soil Tillage Res. 2011, 112, 107-113. [CrossRef]

59. Dignac, M.-F.; Derrien, D.; Barre, P.; Barot, S.; Cécillon, L.; Chenu, C.; Chevallier, T.; Freschet, G.T.; Garnier, P.; Guenet, B. Increasing soil carbon storage: Mechanisms, effects of agricultural practices and proxies. A review. Agron. Sustain. Dev. 2017, 37, 14. [CrossRef] 
60. Wang, Q.; Bai, Y.; Gao, H.; He, J.; Chen, H.; Chesney, R.; Kuhn, N.; Li, H. Soil chemical properties and microbial biomass after 16 years of no-tillage farming on the Loess Plateau, China. Geoderma 2008, 144, 502-508. [CrossRef]

61. Kumawat, C.; Sharma, V.; Meena, M.; Dwivedi, B.; Barman, M.; Kumar, S.; Chobhe, K.A.; Dey, A. Effect of crop residue retention and phosphorus fertilization on $\mathrm{P}$ use efficiency of maize (Zea mays) and biological properties of soil under maize-wheat (Triticum aestivum) cropping system in an Inceptisol. Indian J. Agric. Sci. 2018, 88, 1184-1189.

62. Muzangwa, L.; Mnkeni, P.N.S.; Chiduza, C. The Use of Residue Retention and Inclusion of Legumes to Improve Soil Biological Activity in Maize-Based No-Till Systems of the Eastern Cape Province, South Africa. Agric. Res. 2020, 9, 66-76. [CrossRef]

63. Ramesh, T.; Bolan, N.S.; Kirkham, M.B.; Wijesekara, H.; Kanchikerimath, M.; Rao, C.S.; Sandeep, S.; Rinklebe, J.; Ok, Y.S.; Choudhury, B.U. Soil organic carbon dynamics: Impact of land use changes and management practices: A review. In Advances in Agronomy; Elsevier: Amsterdam, The Netherlands, 2019; Volume 156, pp. 1-107.

64. Choudhary, M.; Datta, A.; Jat, H.S.; Yadav, A.K.; Gathala, M.K.; Sapkota, T.B.; Das, A.K.; Sharma, P.C.; Jat, M.L.; Singh, R. Changes in soil biology under conservation agriculture based sustainable intensification of cereal systems in Indo-Gangetic Plains. Geoderma 2018, 313, 193-204. [CrossRef]

65. Peters, R.; Sturz, A.; Carter, M.; Sanderson, J. Developing disease-suppressive soils through crop rotation and tillage management practices. Soil Tillage Res. 2003, 72, 181-192. [CrossRef]

66. Ghimire, R.; Norton, J.B.; Stahl, P.D.; Norton, U. Soil microbial substrate properties and microbial community responses under irrigated organic and reduced-tillage crop and forage production systems. PloS ONE 2014, 9, e103901. [CrossRef] [PubMed]

67. Zhu, L.; Hu, N.; Yang, M.; Zhan, X.; Zhang, Z. Effects of different tillage and straw return on soil organic carbon in a rice-wheat rotation system. PLoS ONE 2014, 9, e88900. [CrossRef] [PubMed]

68. Cotrufo, M.F.; Wallenstein, M.D.; Boot, C.M.; Denef, K.; Paul, E. The M icrobial E fficiency-M atrix S tabilization (MEMS) framework integrates plant litter decomposition with soil organic matter stabilization: Do labile plant inputs form stable soil organic matter? Glob. Chang. Biol. 2013, 19, 988-995. [CrossRef]

Publisher's Note: MDPI stays neutral with regard to jurisdictional claims in published maps and institutional affiliations.

(C) 2020 by the authors. Licensee MDPI, Basel, Switzerland. This article is an open access article distributed under the terms and conditions of the Creative Commons Attribution (CC BY) license (http://creativecommons.org/licenses/by/4.0/). 